\title{
Pierre Robin syndrome-faciodigital anomaly syndrome
}

INSERM

\section{Source}

INSERM. (1999). Orphanet: an online rare disease and orphan drug data base. $\underline{\text { Pierre }}$ Robin syndrome-faciodigital anomaly syndrome. ORPHA:2888

This syndrome is characterised by the association of Pierre Robin sequence (retrognathia, cleft palate and glossoptosis) with facial dysmorphism (high forehead with frontal bossing) and digital anomalies (tapering fingers, hyperconvex nails, clinodactyly of the fifth fing ers and short distal phalanges, finger-like thumbs and easily subluxated first metacarpophalangeal joints).Growth and mental development were normal. 